\title{
The normative origins of democracy in the European Union: toward a transformationalist theory of democratization
}

\author{
FRANK SCHIMMELFENNIG * \\ Center for Comparative and International Studies, ETH Zurich, Switzerland
}

\begin{abstract}
Institutional democratization has made considerable progress in the history of the European Union (EU). Mainstream theories of democratization, however, fail to capture this process because they are wedded to the nation-state context. This paper therefore proposes a transformationalist theory of democratization beyond the state. EU democratization results from the conflict about the redistribution of political competences between institutional actors in a multilevel system, in which liberal democracy is the shared norm of legitimate authority. To the extent that institutional actors, who push for further integration in order to increase efficiency, undermine existing democratic institutions at the national level, their competitors can put into question the legitimacy of integration by invoking the shared liberal democratic community norms and shame them into making democratic concessions. The normative origins of democracy in the EU are illustrated in case studies on democratic membership conditionality, legislative rights of the European Parliament, and the institutionalization of human rights in the EU.
\end{abstract}

Keywords: democracy; democratization; European Union

\section{Introduction}

The considerable expansion of the scope and level of European integration since the end of the 1980s has given rise to a burgeoning literature on its consequences for democracy. ${ }^{1}$ Almost all of this literature is normative, evaluative, and prescriptive: it discusses the appropriate standards for democracy in the European Union (EU), assesses the state of democracy in the EU against these standards, and makes suggestions for improvement. This paper takes a different perspective. It starts from the substantial institutional democratization that the EU has undergone in its history with regard to membership, the power of parliament, and human rights. Rather than evaluating these changes against a normative yardstick, it asks why and how democratization has occurred. Standard theories of democratization, however, fail to provide convincing explanations because they

\footnotetext{
* E-mail: schimmelfennig@eup.gess.ethz.ch

${ }^{1}$ For recent overviews of the debate on the EU's democratic deficit, see Jensen (2009) and Rittberger (2010).
} 
are too strongly wedded to the nation-state to capture the specific dynamics in the European multilevel system. In particular, the demand-side conditions prevalent in analyses of nation-state democratization are conspicuously absent in the EU: a culturally integrated and politically structured demos, redistributive conflict between elites and citizens, and social unrest creating revolutionary threats.

This paper therefore proposes a 'transformationalist' theory of democratization in the European multilevel system. Transformationalist theories dispute the gradualist claim that democracy and democratization in the international domain are simply the extension of nation-state democracy and democratization on a larger scale. $^{2}$ They regard both as qualitatively different and the difference as a result of a new 'transformation of democracy' (Dahl, 1989, 1994). Whereas theories of democratization generally assume the pre-existence of a single demos, the EU consists of multiple political communities. Moreover, the EU lacks the centralized powers of coercion, taxation, and redistribution that democratic movements have traditionally mobilized against and sought to bring under popular control. On the other hand, however, the EU's multinational and multilevel system is embedded in a community of values in which liberal democracy is the accepted standard of legitimate political authority.

I argue that democratization in this context is the outcome of constitutional conflict between institutional actors in the EU multilevel system. The powerful actors in this system push for further integration in order to increase efficiency without paying much attention to democratic legitimacy. Weak actors, however, can put into question the legitimacy of integration and put normative pressure on the powerful actors if they undermine generally accepted liberal democratic institutional norms. At important critical junctures in the history of European integration, powerful institutional actors have adopted liberal democratic norms at the European level in order to preserve the legitimacy of the integration process and of their position in the multilevel system. It is for that reason that I speak of the normative origins of democracy in the EU and distinguish it from the economic or social origins of democracy highlighted in studies of the nation-state (Moore, 1966; Acemoglu and Robinson, 2006).

The paper proceeds as follows. In the next section, I briefly describe important developments in the institutional democratization of the EU. In search of an explanation, I then turn to theories of nation-state democratization. In response to their limits, I develop my own argument about the normative origins of democracy in the EU. To substantiate the argument empirically, I present three brief case studies on the introduction of the democratic membership norm, legislative competences for the European Parliament (EP), and human rights into European law. The main focus of the paper, however, is on conceptualization and theory development rather than empirical analysis.

\footnotetext{
2 On gradualism and transformationalism in democratic theory, see e.g. Held et al. (1999: 7-9) and Bohman (2007: 20-30).
} 


\section{Democratization in the EU}

I will first give a brief overview of the community's 50-year trajectory from an international organization with very limited traits of democracy to one that has the major institutional trappings of a democratic polity. The analysis will be based on a formal and rather minimalist definition of democracy. For one, I base my claim on the formal rights and competencies codified in EU treaty law. Moreover, I will limit myself to three constitutive institutions of liberal democracy. First, the representative assembly, which aggregates the preferences of the citizens, passes laws, and monitors the executive; second, the human rights regime that serves to protect the fundamental negative and positive freedoms of the citizens; and third, the membership regime that determines who is entitled to join the polity and enjoy the rights it confers on its members. The overview will focus on the initial state of democracy according to the Treaties of Rome (signed in 1957) and the current state of democracy according to the Treaty of Lisbon (signed in 2007).

\section{Democratic membership}

For democracy in a multilevel polity such as the EU, it is essential that all member states are democratic. Article 237 of the Treaty establishing a European Economic Community simply stated that 'any European state may apply to become a member of the Community' and left it to the member state governments to decide unanimously on the application. No further criteria were explicitly attached. The new Article 49 as amended by the Treaty of Lisbon reads: 'Any European State which respects the values referred to in Article 2 and is committed to promoting them may apply to become a member of the Union'. These values are 'respect for human dignity, freedom, democracy, equality, the rule of law, and respect for human rights, including the rights of persons belonging to minorities'. That is, the Union is now explicitly constituted as a union of democratic European states.

\section{Powers of the parliament}

Under the Treaties of Rome, the Assembly was composed of delegates from national parliaments. Whereas it had no business in the appointment of the Commission, it had the right to adopt a motion of censure causing the entire Commission to resign. With regard to the budget and to legislation, the Assembly only had a consultative role, that is, no formal power over the final decision. According to the Treaty of Lisbon, the co-decision procedure is the 'ordinary legislative procedure' applied to the vast bulk of the EU's legislation. Under this procedure, the EP is put on an equal footing with the Council in deciding legislation. Budgetary decision-making is now similar to co-decision insofar as it requires the consent of the $\mathrm{EP}$ and envisages a conciliation process in case the Council and the EP do not reach agreement. Finally, the role of the EP in the appointment of the Commission has been strengthened over time. Whereas the 
European Council still proposes the candidate for Commission President, it does so 'taking into account the elections to the EP', which means that the party affiliation of the President is likely to mirror that of the majority (coalition) in Parliament. The appointment of the Commission President as well as that of the entire Commission is subject to the EP's consent. In the new Article 10, the Treaty now stipulates that 'the functioning of the Union shall be founded on representative democracy'. It creates a roughly balanced bicameral legislature, in which one chamber - the EP - represents the individual citizens, and the other - the Council - the member states. Because member states are democracies, both chambers of the Union legislature are democratically legitimated.

\section{Human rights}

The treaties of Rome did not contain any general human rights provisions, nor did they accord the supranational organs of the Community any competences in this area. According to the new treaty, however, the Charter of Fundamental Rights of 2000, which includes a broad set of rights but had only been politically binding before, possesses 'the same legal value as the Treaties' (Article 6.1). In addition, the EU commits itself to acceding to the European Human Rights Convention. That is, the Union will not only have its own legally enforceable human rights catalog, but will also be subject to the same independent external rights review as its member states.

In sum, in the course of the past 50 years, the European Community has evolved from a regional organization unconcerned with human rights or the regimes of new member states, and featuring no more than a symbolic parliamentary representation, into a liberal democratic multilevel polity. In this polity, composed of democratic states, policies are co-decided by a bicameral legislature of which both chambers are democratically accountable and constrained by human rights norms and human rights review. This substantial institutional democratization requires explanation.

\section{The puzzle of EU democratization}

A natural place to look for an explanation of EU democratization is the literature on state democratization. Because the processes of centralization, legalization, and the expansion of its policy scope have increasingly added state-like authority to the EU, and the EU has adopted many liberal democratic institutions of the state, it seems plausible to assume that the EU has been influenced by the same factors and forces that have contributed to the democratization of the state in the past.

Traditionally, the study of democratization has been divided between the study of structural prerequisites of democracy (in the tradition of modernization theory; cf. Lipset, 1959) and the study of transitions focusing on strategic decision-making (cf. O’Donnell et al., 1986; Przeworski, 1992). Two major recent contributions to 
the theory of democratization, Carles Boix's Democracy and Redistribution (2003) and Daron Acemoglu and James Robinson's Economic Origins of Dictatorship and Democracy (2006), seek to overcome this divide by combining the analysis of elitemass interactions with the structural conditions that constrain them. They are therefore a useful starting point.

In their perspective, democracies are understood as regimes in which the entire (adult) population takes part in the political allocation of economic assets. Democratization is the shift to a regime in which taxation and distribution follow the preferences of the majority rather than that of small, affluent elites. Whether or not it occurs depends on the preferences and resources of both elites and masses or citizens. Elites will more likely consent to democracy if the redistributive impact is low or if they lack the repressive capabilities to quell revolts. Citizens are more likely to revolt successfully if they have strong organizational capacity and experience high economic deprivation. Elites weigh the costs of redistribution against the costs of repression, and masses weigh the benefits of redistribution against the costs of revolt.

According to Boix, 'democracy prevails when either economic equality or capital mobility are high' (2003: 3). Economic equality reduces the redistributive pressure on the elites, and capital mobility allows them to move their assets abroad if taxes become too high. As Acemoglu and Robinson point out, however, too much equality will in turn reduce the pressure of the lower classes for change so that a medium range of inequality is most conducive to democratization (2006: 37). Under these conditions, actual democratization will be precipitated by a revolutionary threat created by social unrest, political mobilization of the lower classes, and/or the weakening of the elites, for example, as a result of interstate conflict (Boix, 2003: 13; Acemoglu and Robinson, 2006: 27).

How plausible is this account of democratization in the case of the EU? In general, the elite- or supply-side conditions of democratization are favorable. First, the EU has not only some of the highest standards of living in the world but also Europe is the region with the world's lowest inequality. ${ }^{3}$ Second, capital mobility is high - not only within the EU but also beyond the EU borders, thus dampening the potential redistributive consequences of EU democratization. Third, the repressive capacities of the EU are extremely weak or, more precisely, extremely decentralized. Control over the means of force, the military, and the police rest firmly with the states. Not only would the member states have to overcome the collective action problems of repressing an anti-EU revolt but also, as liberal democratic states, they are institutionally constrained in the use of force against their citizens. In sum, with low costs of redistribution and high costs of

\footnotetext{
3 According to the IMF, the EU's GDP (PPP) per capita in 2007 was above US \$28,000. The Gini index for the EU is approximately at 30 (out of 100 indicating perfect inequality) (see data at http:// www.eurofound.europa.eu/areas/qualityoflife/eurlife/index.php?template $=3 \&$ radioindic $=158$ \&idDomain $=3$, retrieved 6 March 2010).
} 
repression, elites would have neither the motivation nor the means to suppress strong societal demand for EU democratization.

By contrast, the demand-side conditions are unfavorable. First, the comparatively high wealth and low inequality of the region does not create significant social pressure. Because all member states are democratic welfare states, the objectives of democratization were already realized at this level of the EU system in the past. Second, even if European integration produced losers and higher inequality, grievances would need to be directed at the national governments rather than the EU. The most relevant decisions on taxation and redistribution are made at the national level. The EU has no power over direct taxation and the most important systems of social insurance (public welfare, health, and pensions) are regulated and administered almost exclusively by the member states.

Accordingly, social protest directed at the EU has remained weak so far. Research by Doug Imig and Sidney Tarrow shows that the politics of protest in Europe is predominantly domestic. Only $5 \%$ of protest activities in the period from 1984 to 1997 addressed EU policy (Imig, 2002: 921). Even though protest against the EU has increased in the 1990s, conflict over European policies is most often 'domesticated'; rather than protesting against the EU directly, nationally organized groups turn to their national governments for support (Imig and Tarrow, 2001: 3, 17-18). Finally, protest against EU policy is mostly accompanied by calls for national protection rather than positive integration (Imig, 2002: 928).

The weakness, domestication, and anti-integrationist orientation of EU-related protest politics points to deeper structural problems of EU democratization. These problems can be summarized under the 'no demos' thesis, which stipulates that the EU cannot democratize because there is no European demos. For a demos to exist, individuals must identify themselves and each other as members of a single political community. In addition, the demos needs to be capable of effective political action, that is, to deliberate on politically relevant issues in the public sphere as well as organize and mobilize political interests. These requirements are only weakly developed at the EU level.

Democracy entails majority governments and decisions as well as redistribution. These are easier to accept for the losers if they belong and feel attached to the same community as the majority and the beneficiaries of redistribution. Moreover, the collective action problems of mass mobilization for democratization (Marks, 1992: 58) are more easily overcome if collective identity is strong. Yet national (or subnational) identities and allegiances clearly predominate in the EU. Less than $15 \%$ of the EU population identify themselves exclusively or primarily as Europeans, whereas around $40 \%$ have an exclusive national identity (Fligstein, 2008: 141-142). Moreover, identification with Europe is a class issue. In contrast to national identity, European identity does not unite social classes but is primarily an attribute of the highly educated and well-to-do (Fligstein, 2008: 156). This pattern of national identification has proved extraordinarily stable in the past few decades despite strong growth in institutional integration - and is likely to 
remain so given that crucial resources and institutions of nation-building remain under the control or within the borders of the nation-state: mass media, education, and language (Cederman, 2001: 158-159).

'Democratic politics is in the vernacular'. (Kymlicka, 1999: 121) A common language is not only a fundamentally important building block of shared identity but also a prerequisite for democratic deliberation and mobilization among citizens. Correspondingly, the development of a single European public sphere is severely limited by the extreme linguistic diversity of the EU and is not regarded as a realistic scenario in EU research. But, even the Europeanization, that is, mutual responsiveness, of national public spheres is limited to quality newspapers rather than the audiovisual media used by most citizens and 'to relatively confined issues and time spans' (De Vreese, 2007: 11).

Finally, the demos is not only constituted by a shared collective identity and a common public sphere but also by political structures through which the political preferences resulting from democratic deliberation are mobilized, aggregated, and represented in the political system. Political associations, movement organizations, parties, and their coalitions are such structures. In the analysis of Stefano Bartolini, the democratization of the European states 'was a process of internal voice structuring in externally consolidated and relatively closed territorial systems, whose military, economic, and cultural boundaries had already tended to stabilize' (2005: 89). The differentiation and closure of boundaries and the reduction of exit options for individuals in the emerging European state system triggered the need to articulate grievances vis-à-vis the state and to build political structures for doing so effectively. By contrast, European integration consists in the selective removal of internal boundaries (primarily economic and legal) and the openness of external boundaries (as demonstrated by the successive enlargement of the EU and the flexible integration of non-member countries). This boundary removal and de-differentiation undermines political structuring at the EU level.

As a result, the politicization that is taking place in the EU is resulting in the restructuring of domestic politics rather than political structuring at the European level. First, European integration has contributed to giving new prominence to the non-economic, cultural dimension of the political space dividing the traditionalist and nationalist proponents of cultural demarcation from those of cultural integration (Hooghe et al., 2002; Kriesi et al., 2006). Second, the increased salience of European integration has mostly benefited populist parties of the right that could exploit cultural Euro-skepticism (Kriesi et al., 2006: 929; Hooghe and Marks, 2009: 15-18). Third, the new cleavages and related party contests and protest activities manifest themselves predominantly at the national level (Imig, 2002; Kriesi et al., 2006: 922).

In sum, then, theories that explain democratization as the outcome of redistributive conflict and social revolts do not capture the conditions and mechanisms of democratization in the EU. To the extent that European integration is the 
source of social grievances and political conflict, these conflicts take place in the domestic political systems of the member states and the claimants typically demand more national autonomy rather than more EU democracy. Mainstream theories of state democratization are ill-equipped to explain EU democratization because they assume a centralized state with a mature demos. They are not attuned to the multilevel and multinational realities of the EU, in which the relevant regimes of taxation and redistribution as well as the thick collective identity, public sphere, and political structuring that make up the demos are located at the national rather than the European level. How there can be democratization at the European level in the absence of these conditions is beyond their explanatory scope.

One answer to this puzzle is to deny that what is happening in the EU is or ever could be (real) democratization. Giandomenico Majone, for instance, sees the 'incomplete development, at the EU level, of the practices and institutions of representative democracy' as a 'necessary consequence of the preference of a large majority of European voters and, more fundamentally, of the non-existence of a European demos, not to say, a European nation' (2005: 23-24). In his view, democratic standards are inappropriate for 'an inherently non-majoritarian' and regulatory organization such as the EU in the first place (Majone, 1998: 7; 2005: 37-39). While recognizing that there has been 'institutional democratization', Bartolini regards it as just 'façade electioneering' (2005: xv).

This is not the place to discuss the quality of EU democracy, but these assessments beg several fundamental questions. If it is true that the EU is a non-majoritarian and regulatory organization without a demos, how can we then explain that it has undergone a process of democratization in the past 50 years? And even if democracy at the EU level has its deficits, as Bartolini claims, how could institutional democratization have occurred at all in the absence of political structuring?

\section{The normative origins of democracy in the EU}

The discussion in the previous section suggests that in order to understand and explain democratization beyond the nation-state, a 'gradualist' approach will not suffice. I therefore propose a 'transformationalist' approach to democratization that is in tune with the realities of democracy beyond the nation-state. In particular, this requires theorizing a causal mechanism that explains democratization in the absence of a European demos (European identity, public sphere, and political structuring) and significant powers of taxation, redistribution, and coercion at the supranational level. Whereas in nation-state democratization, '[a]lmost all of the crucial democracy-promoting causal mechanisms involve popular contention ... as correlates, causes, and effects' (Tilly, 2007: 78), this is not the case in EU democratization. I propose a causal mechanism that involves elite (rather than popular) contention concerning constitutional (rather than redistributive) rights and competences in a context of common transnational values and norms (rather than national identities). 
It reflects the attempts of weak or disempowered institutional actors (rather than social groups) to increase their power.

\section{A new transformation of democracy}

According to Robert Dahl (1989, 1994, 1999), democracy was transformed once in the past and may undergo another major transformation in the present. The first transformation was the one from the classical assembly democracy of the Greek (and early modern) city-state to the representative democracy of the modern territorial state, whereas the current transformation affects the modern state under the impact of globalization and international organization. ${ }^{4}$ The main driving force of transformations of democracy is a qualitative increase in the size of the polity, which results in turn from the attempt to preserve its autonomy and efficiency. Whereas the modern territorial state was militarily (Tilly, 1985) and economically (Spruyt, 1996) superior to the city-state, international organizations are capable of regulating economic, environmental, and other social interactions that transcend state boundaries.

The efficiency-driven expansion of the size of the polity, however, involves two main trade-offs for democracy, one regarding citizen participation and influence (Dahl, 1994: 27-31; 1999: 21-22), and the other regarding identity and public spirit (Zürn, 1998: 237-240; see also Dahl, 1994: 32; Hurrelmann and DeBardeleben, 2009). Whereas effectiveness requires increasingly large polities, both participation and identity are maximized in small polities. As a general rule, the larger the polity becomes, the more delegation of power it requires to function efficiently; the longer the chains of delegation between the citizens and their representatives and agents become; and the more indirectly and infrequently citizens participate in political decisions. Finally, the citizens' collective identity and sense of community thin out.

At the very least, these processes develop on different time scales (Zürn, 1992). Whereas the denationalization of social interactions occurs first and fastest, it takes time to establish effective political organizations to regulate these interactions; and it takes even longer for identity and political structuring to build in the new polity. But, even in the long run, participation and identity do not recover their previous levels. In the territorial state, citizen participation has never reached the close involvement of all citizens in everyday decision-making that existed in the Greek polis. Instead, direct democracy has been transformed into representative democracy. Likewise, the tangible, local community of the city-state with its direct interactions and face-to-face communication between citizens has been transformed into the intangible, 'imagined community' of the nation-state, in which 'the members of even the smallest nation will never know most of their fellow-members, meet them or even hear of them' (Anderson, 1991: 6).

\footnotetext{
${ }^{4}$ Dahl counts differently but his first transformation (from oligarchy and despotism to classical democracy) was a transformation $t o$, rather than a transformation of democracy.
} 
Table 1. Transformations of democracy

\begin{tabular}{llll}
\hline \hline & Local democracy & Nation-state democracy & Supranational democracy \\
\hline Space & City-state & Territorial state & Regional organization \\
Community & Local, tangible & National, imagined & Civic, abstract \\
Participation & $\begin{array}{c}\text { Directly by } \\
\text { citizens }\end{array}$ & Indirectly by citizen & More indirectly by citizen and \\
& representatives & community representatives \\
\hline \hline
\end{tabular}

In the EU polity, the thinning of identity and the weakness of citizen participation reach a new quality (see Table 1 ). This polity is a 'community of communities' (Etzioni, 2007) rather than a community of individuals, and it privileges the representation of collectivities over the representation of individuals. First, as shown above, a 'thick', group-based, quasi-national identity has failed to form in the EU and remains firmly entrenched at the national level. By contrast, the identity of the EU is 'thin', civic, based on values and norms, and consists in a commitment to liberal democracy. This is evident from the Treaty on European Union, which stipulates in Article 6.3 that the 'Union shall respect the national identities of its Member States' and in Article 6.1 that the 'Union is founded on the principles of liberty, democracy, respect for human rights and fundamental freedoms, and the rule of law, principles which are common to the Member States'. In other words, the EU is a liberal democratic civic community of national communities. Where cultural similarity is not available anymore across the EU's societies, liberal values, and democratic institutions (in addition to wealth) generate transnational trust (Delhey, 2007).

Second, the EU is a 'mixed' (Majone, 2005: 46-49) or 'compound polity' (Fabbrini, 2007). It is not a polity of citizens possessing popular sovereignty and direct links of election and accountability to their representatives and government but predominantly a polity of corporate bodies, a 'union of states and their citizens' (Fabbrini, 2007: 3). EU citizenship is derived from citizenship in one of the member states. Only the EP is directly elected by citizens - but the EP is neither the exclusive legislator nor does it form a government for the EU. The political system of the EU is characterized by both the vertical separation of power between the supranational and the national levels and by pronounced horizontal checks and balances between political organizations at the supranational level. These structural conditions of a compound polity embedded in a liberal transnational community also shape the process of EU democratization.

\section{Conditions and mechanisms of democratization in the EU}

The main actors in EU democratization are the institutional actors of the European multilevel system: member state governments, their organizations such as the Council, the supranational organizations (European Commission, EP, and 
the European Court of Justice (ECJ)) and also national parliaments and courts. These institutional actors are most likely to compensate the 'demos deficit' of the EU; they possess the organizational capacities for bringing about political change; the elites representing these institutional actors are more multilingual and better equipped to participate in a transnational public sphere; and they identify themselves less exclusively with the nation-state than the average citizen.

These institutional actors are in permanent conflict about the allocation of political rights and competences (rather than economic assets) and about the constitutional principles of the emerging Euro-polity (cf. Farrell and Héritier, 2007). First, there is conflict about which countries are entitled to be in the EU and enjoy the rights of membership. Second, there is conflict about the distribution of competencies between organizations at the same level: the Council, the Commission, the Parliament, and the Court. Third, there is conflict between institutional actors situated at different levels of the multilevel system, for example, between national parliaments, courts, and governments, on the one hand, and the EP, the Court, and the Commission, on the other.

These conflicts between organizations about the allocation of political rights and competences take place within a liberal community. Regardless of their conflicting positions on Europe's informal constitution, all institutional actors share the core values and norms of liberal democracy and accept them as fundamental standards of political legitimacy. The interplay of constitutional conflict between institutional actors, on the one hand, and the consensus on liberal democratic norms, on the other, is at the core of the causal mechanism of democratization in the EU.

In line with liberal intergovernmentalist integration theory (Moravcsik, 1998), the EU's original design as a purely intergovernmental, efficiency-oriented organization can be set as the stylized starting point for the causal story. At the start, competences in the European Communities were allocated in order to ensure the dominance of member state governments. Governments were the only institutional actors with decision-making power (constrained by the agenda-setting power of the Commission but not by either Parliament or judicial human rights review). They also retained the exclusive competence to modify the distribution of competences by way of treaty revision. In addition, however, the Community was designed to prevent member state defection from collectively beneficial intergovernmental bargains. To enhance efficiency, the states accorded the Commission and the Court extensive monitoring and sanctioning competences. What then triggered democratization, a process bound to reduce the power of governments and intergovernmental efficiency?

According to liberal intergovernmentalism, member state governments are willing to accept further integration when it is an efficient way to deal with new or increased international interdependence. However, efficiency-driven integration may at the same time redistribute competences among institutional actors in the EU polity. As a general rule, further integration empowers supranational actors 
vis-à-vis national actors. It also strengthens governments and executives vis-à-vis other actors at the national level (Moravcsik, 1994). In addition, efficiency-driven integration may contradict the constitutional preferences of some EU actors. Under both conditions, the negatively affected actors have an incentive to block or modify integration.

Actors with strong formal or bargaining power (most often the member state governments) can decide the constitutional changes they prefer and veto those they dislike. Weaker actors, however, need to resort to alternative strategies. ${ }^{5}$ At this point, the EU's liberal democratic values and norms come into play. If weak actors can plausibly claim that efficiency-driven integration violates the shared liberal democratic values and norms, they can engage in rhetorical action to prevent or retrieve losses from integration or to attain their constitutional goals (Schimmelfennig, 2001: 62-76; Rittberger, 2005: 59-64). For this purpose, weak actors engage in framing, blaming, and shaming. First, they seek to frame integration as a norms-and-identity issue rather than (just) an issue of efficiency. Second, they draw attention to the fact that the planned efficiency-driven integration violates the fundamental liberal democratic values and norms of the community. In other words, they scandalize the democratic deficit created by integration and blame the powerful actors for being responsible.

The shamed actors can, in principle, respond in three ways: ignore the opponents and go ahead as planned, call off efficiency-driven integration, and make institutional concessions to improve the democratic legitimacy of integration. In general, we can assume that they prefer to reap efficiency gains without compromising their legitimacy and that of European integration. This means that they can only go ahead as planned if the opponents' claim of a democratic deficit is unfounded. Generally, efficiency-driven intergovernmental integration does not create a formal democratic deficit as long as all participating governments are democratically elected, decide unanimously, and remain accountable to national parliamentary scrutiny and judicial human rights review. Accordingly, Berthold Rittberger (2006) has shown that federalist demands for supranational democracy failed in the early integration period because none of these principles were violated. If one of these principles is undermined, however, the proponents of further integration will, if possible, rather consent to incremental democratization than foregoing substantial efficiency gains of integration. The result is an incremental democratization of the EU that follows or accompanies the growth of efficiencyoriented integration.

To summarize, EU democratization results from constitutional conflict among institutional actors about the distribution of political rights and competences in the liberal EU community. This happens under two main conditions: (i) efficiencydriven integration generates a democratic deficit and (ii) negatively affected but

\footnotetext{
${ }^{5}$ Please note that this is not an argument about strong and weak member states. All states have formal veto power and are thus considered strong actors in constitutional politics.
} 
weak institutional actors are able to refer to the EU's liberal democratic values and norms to undermine the legitimacy of efficiency-driven integration and to strengthen their position in the constitutional conflict. Because the shared liberal democratic norms of the transnational European community are the crucial condition for democratization, I speak of the normative origins of democracy in the EU.

\section{Case studies}

In the remainder of the paper, I will briefly illustrate how this mechanism worked at critical junctures for the three major areas of EU democratization described at the beginning: democratic membership conditionality, parliamentary decisionmaking rights, and human rights. Each case represents the historical episode during which the core democratic reforms in these three areas were first introduced. The Spanish application for association to the EU established the norm of democratic membership; the introduction of the cooperation procedure in the Single European Act (SEA) first accorded the EP real legislative power; and the adoption of human rights standards in the jurisdiction of the ECJ introduced human rights to the EU level. ${ }^{6}$ The liberal democratic rights and competences first established during these episodes were subsequently further institutionalized and elaborated. ${ }^{7}$ But, later developments mainly followed the normative precedents set at these critical junctures.

The case studies follow a process tracing rather than a comparative design. In each of them, I seek to demonstrate the core elements of the democratization mechanism theoretically outlined above: how efficiency-oriented steps of further integration triggered constitutional conflict among the EU polity's institutional actors and how formally weak institutional actors were successful in bringing about democratization steps by invoking the EU's liberal democratic standard of legitimacy. Table 2 gives an overview of the cases.

\section{Democratic membership}

In the Treaties of Rome, no explicit conditions were attached to applications for membership in the European Communities - except for being a 'European state'. Soon after the Treaties came into effect, the new organization was faced with several requests for membership and association (with a membership perspective).

\footnotetext{
${ }^{6}$ For the case studies, I draw on a collaborative project with Berthold Rittberger (Rittberger and Schimmelfennig, 2006). For the case study on membership conditionality, I rely on Thomas (2006). For the case study on legislative rights, I draw on Rittberger (2005). Finally, the case study on human rights is based on Schimmelfennig (2006).

${ }^{7}$ Stacey and Rittberger (2003) as well as Farrell and Héritier (2007) analyze such interstitial institutional changes in the EU. Farrell and Héritier explain them as renegotiations of incomplete contracts in which bargaining power rather than rhetorical power mattered.
} 
Table 2. Three critical junctures of democratization in the EU

\begin{tabular}{|c|c|c|c|}
\hline & Membership & Legislation & Human rights \\
\hline Starting point & 'Any European state ...' & EP consultation & $\begin{array}{l}\text { Absence of human } \\
\text { rights provisions }\end{array}$ \\
\hline $\begin{array}{l}\text { Efficiency-oriented } \\
\text { further integration }\end{array}$ & $\begin{array}{l}\text { Territorial expansion of } \\
\text { common market }\end{array}$ & $\begin{array}{l}\text { Majority voting to } \\
\text { complete common } \\
\text { market }\end{array}$ & $\begin{array}{l}\text { ECJ supremacy to } \\
\text { implement common } \\
\text { market }\end{array}$ \\
\hline $\begin{array}{l}\text { Proponents of } \\
\text { efficiency-oriented } \\
\text { integration }\end{array}$ & Member states & Member states & ECJ \\
\hline $\begin{array}{l}\text { Weak/disempowered } \\
\text { opponents }\end{array}$ & EP & Parliaments & $\begin{array}{l}\text { National constitutional } \\
\text { courts }\end{array}$ \\
\hline $\begin{array}{l}\text { Claimed violation of } \\
\text { liberal democratic } \\
\text { norms }\end{array}$ & $\begin{array}{l}\text { Admission of non- } \\
\text { democratic countries }\end{array}$ & $\begin{array}{l}\text { Broken chain of } \\
\text { indirect } \\
\text { accountability }\end{array}$ & $\begin{array}{l}\text { EU law unconstrained } \\
\text { by human rights } \\
\text { (review) }\end{array}$ \\
\hline Outcome & $\begin{array}{l}\text { Democratic membership } \\
\text { conditionality }\end{array}$ & $\begin{array}{l}\text { Legislative rights } \\
\text { for EP }\end{array}$ & $\begin{array}{l}\text { Introduction of human } \\
\text { rights into EU law }\end{array}$ \\
\hline
\end{tabular}

$\mathrm{EU}=$ European Union; EP = European Parliament; ECJ = European Court of Justice.

In the initial debates of how the EC should respond to these requests, the democratic credentials of the candidates did not play a significant role.

When fascist Spain showed interest in closer ties with the EC, this was generally welcomed by the member states. The French and the German governments as well as the Commission regarded Spain as a valuable addition to the emerging common market and encouraged Spain to open negotiations on association and, eventually, membership. Thus, the push toward further integration was driven predominantly by efficiency reasons.

These developments provoked the resistance of the Parliamentary Assembly - a weak actor because, at the time, it did not have any formal say over association and accession. However, it appointed Willi Birkelbach, a German social democrat and victim of the Nazi regime, to draft a report on the association process. For him and his fellow parliamentarians, European integration was not primarily about market efficiency but about the consolidation of peace and democracy in post-war Europe. According to Thomas, 'if they wanted to shape Europe's future, Birkelbach and his EPA colleagues would have to provoke a political crisis and frame the resulting debate with norms that the governments of the Member States would be reluctant to disavow, regardless of their preferences on the issue at hand' (2006: 1197-1198).

The Birkelbach Report referred to the common values of the member states as well as the admission criteria of the Council of Europe (rule of law, human rights, and fundamental freedoms) to assert that states 'whose governments do not have democratic legitimacy and whose peoples do not participate in the decisions of the government, neither directly nor indirectly by freely elected representatives, 
cannot expect to be admitted in the circle of peoples who form the European Communities'. (Birkelbach, 1962, cited in Thomas, 2006: 1198) The arguments of the report were taken up by the press, socialist parties, and trade unions in order to mobilize against the association treaty with Spain.

Faced with increasing normative pressure by the Parliamentary Assembly and in the public, the member state governments generally became more cautious on the issue of Spanish association, and the Benelux countries retreated from their earlier support. In the course of 1962, the member state governments first delayed their decision and then shelved association with Spain. Finally, they signed a simple tariffs agreement in the framework of the GATT. It was not before Spain's transition to democracy in the 1970s that the question of association and membership was taken up again. Spain joined in 1986.

The case shows how an efficiency-oriented move toward further integration with a country that violated generally accepted standards of political legitimacy in the community triggered successful rhetorical action by actors without formal powers or strong bargaining power. Whereas the association and accession of democratic countries like Britain or Switzerland could legitimately be regarded in an efficiency perspective, the Spanish case could be used by those actors with an interest in a democratic European Community to scandalize the narrow efficiency orientation of many member state governments and to introduce democratic membership conditionality. Although it took until the Maastricht Treaty in 1992 to put this conditionality into treaty language, it was generally recognized after the Spanish episode that non-democratic states could not join.

\section{Legislative powers of the EP}

Until the SEA of 1986, the EP did not have any legislative competences apart from being consulted on legislative proposals made by the Commission. The SEA then introduced the cooperation procedure in which the Council decides with qualified majority in the first reading, and the EP can amend or reject the Council's decision. If the EP rejects the proposal, the Council can only uphold it with unanimity. If the EP amends the proposal, the Council is obliged to take the amendments into account insofar as they are taken over by the Commission. For the first time, the SEA thus accorded the EP formal legislative power. How did the cooperation procedure come about?

Throughout the 1980s, federalist governments and parliamentarians had demanded more legislative rights for the EP, but as long as the Council decided with unanimity, the formal chain of democratic accountability remained intact. All democratically elected member state governments could veto legal acts and ensure that none of the constitutive demoi of the Community was overridden. All Council decisions formally benefited from full indirect democratic legitimacy.

When the member states launched the Internal Market Program, however, they also committed themselves to qualified majority voting (QMV). QMV was seen as 
necessary to increase the speed of EC decision-making and to overcome opposition to market-enhancing regulation by individual member states. The rationale for moving from unanimity to QMV was thus efficiency-based. At the same time, however, QMV implied the possibility of overruling individual demoi and their national governments and parliaments. The chain of democratic accountability was thus broken and indirect democratic legitimacy suffered.

This democracy deficit was criticized by members of parliament in national parliaments as well as in the EP who demanded that the loss of indirect democratic legitimacy needed to be compensated by expanding the legislative competences of an organization invested with direct democratic legitimacy: the EP (Rittberger, 2005: 150-152). Although most member state governments were not sincerely committed to increasing the powers of the EP and realized that this would undermine both legislative efficiency and their own powers (Rittberger, 2005: 163, 165), they acquiesced to the demands of parliamentarians. By contrast, some member states like Denmark and the United Kingdom opposed empowering the EP. Because their domestic audiences were critical toward supranational integration, they were not under pressure to grant more legislative powers to the EP. Rather, they stressed the need to preserve efficiency.

This case shows how an efficiency-based claim for the deepening of European integration undermined democratic accountability and (indirect) democratic legitimacy and triggered demands by national and European parliamentarians for compensatory democratization at the EU level. Democratic accountability (including the parliamentary accountability of governments) is a shared norm in the community. As a result, even the governments that were most skeptical of the strengthening of supranational organizations consented to extending the EP's powers in the end.

Yet the establishment of the Cooperation Procedure is not as clear a case of effective rhetorical action as the establishment of democratic membership conditionality. First, even though 'non-ratification was never a real threat' (Rittberger, 2005: 167), national parliaments could have rejected the SEA in principle unless their demands for EP empowerment were accommodated. They were thus not as institutionally weak as the Parliamentary Assembly in the case of Spanish association. Second, the Cooperation Procedure was a compromise solution designed to meet the British efficiency concerns (Rittberger, 2005: 169). The British consent thus did not result from normative pressure. Finally, the strongest provision of the Cooperation Procedure - that the Council needed unanimity to overrule the EP's rejection of a legislative proposal - was the outcome of a last-minute veto threat of the Italian government (Rittberger, 2005: 169). In sum, whereas the governments' weakening of democratic accountability for reasons of market-making efficiency triggered rhetorical action by the less powerful institutional actors - the national and Euro-parliamentarians - the eventual introduction of EP legislative powers was partly the result of efficiency-based compromises and veto threats.

In the Treaty of Maastricht, the Codecision Procedure, which extended the legislative powers of the EP, replaced the Cooperation Procedure in most cases. 
But, the norm that QMV in the Council must be complemented by an empowerment of the EP has remained a fundamental principle of institutional reform in the EU.

\section{Human rights}

The initial steps of institutionalizing human rights in the Community were taken by the ECJ in its case law from the late 1960s onward. It was only in the preamble of the SEA of 1986 that human rights featured in an intergovernmental treaty of the Community for the first time and in a purely declaratory manner.

In its two landmark decisions Van Gend en Loos (1963) and Costa (1964), the ECJ claimed the direct effect and supremacy of EC law. According to the ECJ, the EC would not be able to attain its central goal of creating a common market otherwise. The claim for supremacy was thus clearly based on efficiency. Naturally, supremacy referred not only to EC law but also to the ECJ. In all matters pertaining to EC law, the ECJ would come out at the top of the European multilevel court system. The ECJ's efficiency-oriented move thus created institutional losers from integration, above all the highest national courts.

At the same time, the supremacy claim created a legitimacy deficit. Supremacy applied not only to ordinary domestic law but also to national constitutional law and the individual rights and freedoms protected under it. National constitutional review was effectively suspended for issues regulated by EC law. At the same time, there was no EC system of human rights protection. As a result, direct effect and supremacy threatened to reduce the level of human rights protection in the Community. This legitimacy gap could be used by national courts to challenge the supremacy claim.

The most explicit challenge came with the Internationale Handelsgesellschaft case, which had its roots in a referral to the ECJ by a German administrative court, which claimed that EC provisions were 'contrary to certain structural principles of national constitutional law that must be protected within the framework of community law, with the result that the primacy of supranational law must yield before the principles of the German Basic Law'. ${ }^{8}$ In its decision of 17 December 1970, the Court conceded that such community measures needed to be subject to constitutional human rights review in principle (thus paying tribute to the community's standard of legitimacy). However, it rejected the argument for national constitutional review.

In fact, respect for fundamental rights forms an integral part of the general principles of law protected by the Court of Justice. The protection of such rights, while inspired by the constitutional traditions common to the member states, must be ensured within the framework of the structure and objectives of the community. ${ }^{9}$

${ }^{8}$ ECJ, Internationale Handelsgesellschaft v Einfuhr- und Vorratsstelle für Getreide- und Futtermittel, Case 11/70.

${ }^{9}$ Ibid. 
This was an attempt by the ECJ to silence national courts by showing that it used their standards of human rights protection and that there was no legitimacy deficit that would justify challenging the supremacy of the ECJ. The German administrative court, however, did not accept this preliminary ruling and referred the case to the German Federal Constitutional Court (FCC). In the meantime, the ECJ added another 'source of inspiration' to its human rights jurisdiction in its Nold decision (1974), in which it included international treaties such as the European Convention of Human Rights to the guidelines it would follow in its legal practice. ${ }^{10}$ The general strategy of the ECJ was to argue that all human rights otherwise observed by the member states and enforced by national and international systems of human rights protection would also be protected in the EC legal system.

For the time being, however, the FCC did not accept this conclusion. Two weeks after Nold, it issued its ruling on the referral of the Internationale Handelsgesellschaft case. Although it found no violation of German constitutional rights in this particular case, it used the occasion to make the general statement that, 'as long as the integration process has not progressed so far that Community law also contains an explicit catalog of fundamental rights, passed by a Parliament, valid and equivalent to the catalog of fundamental rights of the Basic Law', national courts would have the right and, indeed, the obligation to refer the case to the FCC for constitutional review if they deemed the preliminary ruling of the ECJ to collide with fundamental rights as protected by the Basic Law. ${ }^{11}$ The FCC rejected the supremacy of EC law as a general principle and limited the direct effect of EC law to those provisions that did not encroach upon essential elements of constitutional structure - in particular the Basic Law's catalog of fundamental rights.

This decision gave the supranational institutionalization of human rights further impetus. First, the ECJ made increasingly detailed use of the European Convention to imbue its case law with legitimacy. However, the Court could not do anything on its own to meet the other thresholds of legitimacy claimed by the FCC in 1974. For that, it required the assistance of other Community actors. In 1977, the EP, the Council, and the Commission published a joint declaration 'concerning the protection of fundamental rights', in which they repeated the ECJ's assertions on the respect of the Community's legal system for fundamental human rights as found in the constitutions of the member states and the European Convention. In their 1978 'Declaration on Democracy', the heads of state and government aligned themselves with the interinstitutional declaration. In the preamble to the SEA, the member states then proclaimed their determination 'to work together to promote democracy on the basis of the fundamental rights recognized in the constitutions and laws of the Member States, in the Convention for the Protection of Human Rights and Fundamental Freedoms and the European

${ }^{10}$ ECJ, Nold vs. Commission, Case 4/73.

${ }^{11}$ Bundesverfassungsgericht, Solange I, BVerfGE 37, 271, author's translation. 
Social Charter, notably freedom, equality, and social justice'. ${ }^{12}$ The transfer of case law to treaty law via political declarations added further legitimacy to the ECJ's rulings.

As a result, in its Solange II decision of October 1986, the FCC ruled that 'as long as the European Communities, in particular the jurisdiction of the Court of Justice of the Communities, generally guarantee an effective protection of fundamental rights ... which is equivalent in principle to the protection of fundamental rights required as indispensable by the Basic Law ... the Federal Constitutional Court will cease to exercise its jurisdiction on the applicability of secondary Community law ... and to review the compatibility of this law with the fundamental rights of the Basic Law'. ${ }^{13}$

This case shows that the introduction of human rights to the EC resulted from the competition of two courts located at different levels of the European multilevel system. The ECJ's efficiency-based claim for supremacy was challenged by the FCC on the grounds that human rights protection in the EC was inadequate. This challenge drew on the shared norm that political decisions and laws must be constrained by human rights and subject to human rights review. In order to uphold its claim for supremacy of EC law and the efficiency of market integration, the ECJ therefore had to include the respect for human rights into Community law and human rights review into its own practice.

It is a peculiarity of this case that none of the main opponents was formally more powerful than the other. There is no established hierarchy between the European and the national legal orders. The result was a double rhetorical entrapment. On the one hand, the ECJ needed to introduce human rights review at the European level to strengthen its claim of supremacy. On the other hand, the FCC felt compelled to accept this claim provisionally after the ECJ had complied with the standard of legitimacy.

The three critical junctures in the EU's history of institutional democratization share several commonalities. In all cases, efficiency-oriented moves toward further European market integration challenged democratic norms. Moreover, institutional actors that did not have the formal or bargaining power to block these moves invoked the shared liberal democratic norms of the community and prompted the integration-Friendly actors to introduce democratic rules and institutions at the EU level. In sum, the cases conform to the assumption that democratization in the EU takes place as a result of constitutional conflict between institutional actors in the context of a transnational community of liberal democratic values and norms.

These commonalities have brought about democratization against the background of otherwise distinct conditions at each critical juncture: different liberal democratic norms, different constellations of actors, and different configurations of formal power between the opponents and the proponents.

12 Official Journal L 169, 29 June 1987.

${ }^{13}$ Bundesverfassungsgericht, Solange II, BVerfGE 73, 339, author's translation. 


\section{Conclusions}

In the EU, institutional democratization has taken place under conditions and in ways that standard theories of nation-state democratization with their focus on popular contention and economic redistribution are unable to capture. I have therefore proposed a transformationalist analysis that takes into account the specific conditions of the EU multilevel system. The fact that the EU is composed of democratic welfare states has a triple effect on democratization at the supranational level. First, the powers of coercion, taxation, and redistribution remain under the primary control of, and subject to democratic accountability in, the member states. This makes the traditional reasons for democratization obsolete and explains why theories of state democratization do not fit. Second, however, the efficiency-oriented reallocation of political competences from the national to the supranational level and in favor of executives and agencies tends to devaluate traditional democratic institutions and processes. This creates new demand for democratization - especially by those institutional actors that have a weak position in the European multilevel system or lose competences as a result of European integration. Finally, liberal democracy is the shared standard of legitimate authority in the EU system and thus provides a powerful normative resource for the proponents of supranational democratization. In an international organization originally designed to maximize intergovernmental efficiency, the shared norms of liberal democracy could be used rhetorically by weak institutional actors to increase their negotiating power in constitutional conflicts, to constrain the more powerful actors, and to attain their constitutional goals. In this sense, the origins of democracy in the EU have been normative rather than economic or social.

I illustrated the transformationalist theory of democratization empirically in three cases that were arguably the most important critical junctures for establishing the core liberal democratic norms of membership, parliamentary legislation, and human rights review in the EU. As other studies have shown, the further elaboration and institutionalization of these norms have involved different negotiating mechanisms than rhetorical action (see, e.g., Hix, 2002; Farrell and Héritier, 2007). But they confirm the transformationalist view that democratization in the EU is a process of constitutional conflict between institutional actors.

Future research should seek to establish to what extent this theory of democratization is relevant beyond the EU. For one, the EU experience could be compared with democracies that developed in initially decentralized multilevel systems such as the United States or Switzerland. Another axis of comparison could be other regional organizations. Possibly, however, such comparisons would rather show the particularities of EU democratization than the generalizability of the transformationalist approach proposed here. Regarding other regional organizations, for instance, it presupposes the rare case of a supranational organization of exclusively democratic states. Without supranational integration, there is no need to compensate the loss of democratic autonomy and competences at the 
national level by democratizing the supranational level. Without democratic membership, there is no shared standard of democratic legitimacy that would put normative pressure on powerful (state) actors in favor of democratization.

\section{Acknowledgements}

This paper was written in the context of the NCCR 'Challenges to Democracy in the 21st Century' (IP2). Funding by the Swiss National Science Foundation is gratefully acknowledged. The paper draws on empirical results from an earlier project on the 'Constitutionalization of the European Union' that I co-directed with Berthold Rittberger and that was funded by the Thyssen Foundation. For comments on previous drafts, I thank Hanspeter Kriesi, the reviewers, and audiences at the University of Colorado (Boulder), the University of Washington (Seattle), and the Joint Conference of the Austrian, German, and Swiss Political Science Associations in Osnabrück.

\section{References}

Acemoglu, D. and J.A. Robinson (2006), Economic Origins of Dictatorship and Democracy, Cambridge: Cambridge University Press.

Anderson, B. (1991), Imagined Communities. Reflections on the Origin and Spread of Nationalism, 2nd edn, London: Verso.

Bartolini, S. (2005), Restructuring Europe. Centre Formation, System Building, and Political Structuring Between the Nation State and the European Union, Oxford: Oxford University Press.

Birkelbach, W. 1962. 'Rapport fait au nom de la commission politique sur les aspects politiques et institutionnels de l'adhésion ou de l'association à la Communauté'. Assemblée Parlementaire Européenne, Documents de Séance, 1961-1962, Document 122, 15 Janvier.

Bohman, J. (2007), Democracy Across Borders. From Demos to Demoi, Cambridge, MA: MIT Press.

Boix, C. (2003), Democracy and Redistribution, Cambridge: Cambridge University Press.

Cederman, L.-E. (2001), 'Nationalism and bounded integration: what it would take to create a European Demos', European Journal of International Relations 7(2): 139-174.

Dahl, R. (1989), Democracy and its Critics, New Haven, CT: Yale University Press.

- (1994), 'A democratic dilemma', Political Science Quarterly 109(1): 23-34.

- (1999), 'Can international organizations be democratic? A skeptic's view', in I. Shapiro and C. Hacker-Cordon (eds), Democracy’s Edges, Cambridge: Cambridge University Press, pp. 19-36.

De Vreese, C.H. (2007), 'The EU as a public sphere', Living Reviews in European Governance 2(3). Retrieved 23 April 2010 from http://www.livingreviews.org/lreg-2007-3

Delhey, J. (2007), 'Do enlargements make the European Union less cohesive? An analysis of trust between EU Nationalities', Journal of Common Market Studies 45(2): 253-279.

Etzioni, A. (2007), 'The community deficit', Journal of Common Market Studies 45(1): 23-42.

Fabbrini, S. (2007), Compound Democracies. Why the United States and Europe are Becoming Similar, Oxford: Oxford University Press.

Farrell, H. and A. Héritier (2007), 'Codecision and institutional change', West European Politics 30(2): 285-300.

Fligstein, N. (2008), Euroclash. The EU, European Identity, and the Future of Europe, Oxford: Oxford University Press.

Held, D., A. McGrew, D. Goldblatt and J. Perraton (1999), Global Transformations, Stanford: Stanford University Press. 
Hix, S. (2002), 'Constitutional agenda-setting through discretion in rule interpretation: why the European Parliament won at Amsterdam', British Journal of Political Science 32(2): 259-280.

Hooghe, L. and G. Marks (2009), 'A postfunctionalist theory of European integration: from permissive consensus to constraining dissensus', British Journal of Political Science 39(1): 1-23.

Hooghe, L., G. Marks and C.J. Wilson (2002), 'Does left/right structure party competition on European Integration?', Comparative Political Studies 35(8): 965-989.

Hurrelmann, A. and J. DeBardeleben (2009), 'Democratic dilemmas in EU multilevel governance: untangling the Gordian knot', European Political Science Review 1(2): 229-247.

Imig, D. (2002), 'Contestation in the streets: European protest and the emerging European Polity', Comparative Political Studies 35(8): 914-933.

Imig, D. and S. Tarrow (2001), 'Studying contention in an emerging polity', in D. Imig and S. Tarrow (eds), Contentious Europeans. Protest and Politics in an Emerging Polity, Lanham: Rowman \& Littlefield, pp. 3-26.

Jensen, T. (2009), 'The democratic deficit of the European Union', Living Reviews in Democracy 1(2). Retrieved 23 April 2010 from http://democracy.livingreviews.org/index.php/lrd/article/view/ lrd-2009-2

Kriesi, H., E. Grande, R. Lachat, M. Dolezal, S. Bornschier and T. Frey (2006), 'Globalization and the transformation of the national political space: six European countries compared', European Journal of Political Research 45(6): 921-957.

Kymlicka, W. (1999), 'Citizenship in an era of globalization: a comment on held', in I. Shapiro and C. Hacker-Cordón (eds), Democracy's Edges, Cambridge: Cambridge University Press, pp. 112-126.

Lipset, S.M. (1959), 'Some social requisites of democracy: economic development and political legitimacy', American Political Science Review 53(1): 69-105.

Majone, G. (1998), 'Europe's “Democratic Deficit”: the question of standards', European Law Journal 4(1): 5-28.

- (2005), Dilemmas of European Integration, Oxford: Oxford University Press.

Marks, G. (1992), 'Rational sources of Chaos in democratic transition', in G. Marks and L. Diamond (eds), Reexamining Democracy. Essays in Honor of Seymour Martin Lipset, Newbury Park, CA: Sage, pp. 47-69.

Moore, B. Jr (1966), Social Origins of Democracy and Dictatorship: Lord and Peasant in the Making of the Modern World, Boston, MA: Beacon Press.

Moravcsik, A. 1994. 'Why the European Union strengthens the state: domestic politics and international cooperation. CES Working Paper 52, Harvard University: Center for European Studies.

- (1998), The Choice for Europe: Social Purpose and State Power from Messina to Maastricht, Ithaca, NY: Cornell University Press.

O’Donnell, G., P.C. Schmitter and L. Whitehead (eds) (1986), Transitions from Authoritarian Rule: Comparative Perspectives, Baltimore, MD: The Johns Hopkins University Press.

Przeworski, A. (1992), 'The games of transition', in S. Mainwaring, G. O’Donnell and J. S. Valenzuela (eds), Issues in Democratic Consolidation. The New South American Democracies in Comparative Perspective, Notre Dame: Notre Dame University Press, pp. 105-172.

Rittberger, B. (2005), Building Europe's Parliament. Democratic Representation Beyond the NationState, Oxford: Oxford University Press.

— (2006), “'No integration without representation!” European integration, parliamentary democracy, and two forgotten communities', Journal of European Public Policy 13(8): 1211-1229.

- (2010), 'Democracy and EU governance', in M. Egan, N. Nugent, W. Paterson (eds), Studying the European Union: Current and Future Agendas, Basingstoke: Palgrave, pp. 134-167.

Rittberger, B. and F. Schimmelfennig (2006), 'Explaining the constitutionalization of the European Union', Journal of European Public Policy 13(8): 1148-1167.

Schimmelfennig, F. (2001), 'The community trap: liberal norms, rhetorical action, and the eastern enlargement of the European Union', International Organization 55(1): 47-80.

- (2006), 'Competition and community. Constitutional courts, Rhetorical Action, and the constitutionalization of human rights in the European Union', Journal of European Public Policy 13(8): 1247-1264. 
Spruyt, H. (1996), The Sovereign State and Its Competitors: An Analysis of Systems Change, Princeton, NJ: Princeton University Press.

Stacey, J. and B. Rittberger (2003), 'Dynamics of formal and informal change in the EU', Journal of European Public Policy 10(6): 858-883.

Thomas, D.C. (2006), 'Constitutionalization through enlargement: the contested origins of the EU's democratic identity', Journal of European Public Policy 13(8): 1190-1210.

Tilly, C. (1985), 'War making and state making as organized crime', in P. Evans, D. Rueschemeyer and T. Skocpol (eds), Bringing the State Back In, Cambridge: Cambridge University Press, pp. 169-186.

- (2007), Democratization, Cambridge: Cambridge University Press.

Zürn, M. (1992), 'Jenseits der Staatlichkeit. Über die Folgen der ungleichzeitigen Denationalisierung', Leviathan 20(4): 490-513.

- (1998), Regieren jenseits des Nationalstaats. Globalisierung und Denationalisierung als Chance, Frankfurt: Suhrkamp. 